Article

\title{
Do Corporate Governance Recommendations Apply to U.S. Agricultural Cooperatives?
}

\author{
Jason R. V. Franken ${ }^{1}{ }^{*}$ and Michael L. Cook ${ }^{2}$ \\ 1 School of Agriculture, Western Illinois University, 313 Knoblauch Hall, Macomb, IL 61455, USA \\ 2 Division of Applied Social Sciences, University of Missouri, 125 Mumford Hall, Columbia, MO 65211, USA; \\ cookml@missouri.edu \\ * Correspondence: jr-franken@wiu.edu
}

Received: 7 August 2019; Accepted: 24 September 2019; Published: 26 September 2019

\begin{abstract}
A limited inquiry into cooperative governance and performance suggests that best practices from corporate governance literature may not apply uniformly to cooperatives. The rarely addressed issue of endogeneity limits confidence in recommendations for corporations and cooperatives alike and inference of recommendations for cooperatives is complicated by availability of appropriate performance measures. By accounting for the most commonly recognized sources of endogeneity and measuring overall cooperative performance, expectations of better performance by larger cooperatives with smaller boards are confirmed, while limited evidence is obtained on the expected positive effects of seating outside experts on the board.
\end{abstract}

Keywords: boards of directors; cooperatives; corporate governance; endogeneity; performance

\section{Introduction}

Cooperatives are, by nature, a sustainable and participatory business form that, despite theoretical shortcomings, have shown remarkable resilience in the face of economic and financial crises [1-3]. As a prominent business form in agriculture, cooperative governance and performance is of longstanding interest to economists, policymakers, and industry stakeholders. In contrast to the investor-owned firm (IOF), which strives to maximize return on investment for its shareholders, a cooperative is a user-owned, user-controlled business from which benefits are derived and distributed equally based on use. Existing research evaluates cooperative financial performance as one would profit-maximizing IOFs and fails to account for empirical complications due to endogeneity of governance and performance [4-9]. Moreover, as the (dual) function of cooperatives (i.e., profitability and member benefits) is distinct from that of IOFs [10-13], the same governance recommendations may not apply and alternative performance measures may be appropriate. Researchers take various creative approaches to addressing this aspect of cooperative performance, such as focusing on farm-level patron-member performance [14], using relative productivity measures [15] or computing performance indices from survey responses [16]. Franken and Cook [17] demonstrate that factor analysis [18] of survey and accounting data offers a representative measure of the overall performance of cooperatives.

This article informs governance recommendations specific to U.S. agricultural cooperatives by considering the impact of two of the most prominent aspects of corporate governance research-size of the board of directors and inclusion of expert, outside directors-on cooperative performance [19]. Following Franken and Cook [17], factor analytic techniques are applied to survey and accounting data to measure overall cooperative performance. The effects of past performance on the structure of the board of directors and the tenure of the chief executive officer (CEO) and their impacts on subsequent performance are investigated using three stage least squares (3SLS) estimation-one common method to account for endogeneity that is employed in some corporate governance studies [20]. 
The literature on IOFs initially supports use of smaller boards that include outside directors [19] but support for these generalizations dissipates once endogeneity is addressed [20-23]. While recent innovations in cooperative governance (e.g., hybrid forms, proportional member voting rights, placing professionals/experts on the board of directors, etc.) spark academics' interest [24], existing empirical work on cooperatives, which also infers a negative effect of board size on performance, is limited and neglects the potential endogeneity issues $[4,5]$. As endogeneity has the potential to bias results, it clearly must be addressed to accurately assess the extent to which principles of corporate governance apply to cooperatives. Hence, the relationship between cooperative governance and performance warrants further attention.

\section{Literature and Hypotheses}

Hermalin and Weisbach [19] survey much of the research on corporate governance and chronicle early attempts to address endogeneity. Hence, we commence with their model and adapt it to reflect cooperative governance. The authors summarize the now widely recognized endogenous relationships in the empirical literature with the following system of equations:

$$
\begin{aligned}
& p_{t+s}=\beta a_{t}+\eta_{t} \\
& a_{t+s}=\phi c_{t}+\varepsilon_{t} \\
& c_{t+s}=\mu p_{t}+\xi_{t}
\end{aligned}
$$

where $p$ denotes performance (e.g., profits), $a$ denotes an action of a decision maker (e.g., board dismissal of CEO), $c$ denotes characteristics of decision makers (e.g., board size, CEO tenure), $t$ indexes time $(s>0), \beta, \phi$ and $\mu$ are parameters and $\eta, \varepsilon$ and $\xi$ represent residual errors. Most empirical studies directly estimate impacts of characteristics on performance, essentially substituting Equation (2) into (1). The key point, however, is that the relationships in Equation (3) typically are not taken into account.

Based on their review, Hermalin and Weisbach [19] identify a number of empirical regularities. First, measures of board composition (i.e., inside or employee versus outside directors) meant to indicate board independence appear unrelated to firm performance and firms with smaller boards tend to perform better. Second, board actions reflect board characteristics, as smaller boards with more outside directors make better decisions with respect to executive compensation and CEO replacement, for instance. Finally, bargaining power and turnover of CEOs are sensitive to firm performance and these factors appear to impact board characteristics such as size and composition. This work, as well as more recent research accounting for endogeneity of corporate governance [20-23], is discussed below along with the sparse work on cooperative governance $[5,6]$. Testable hypotheses, developed based on this body of work, are summarized in Figure 1. Note that the circular, endogenous effects stem from past performance. Past performance influences whether a CEO is retained, CEO tenure influences the CEO's ability to negotiate changes to the current board's size, and the current size of the board may affect this year's performance. 


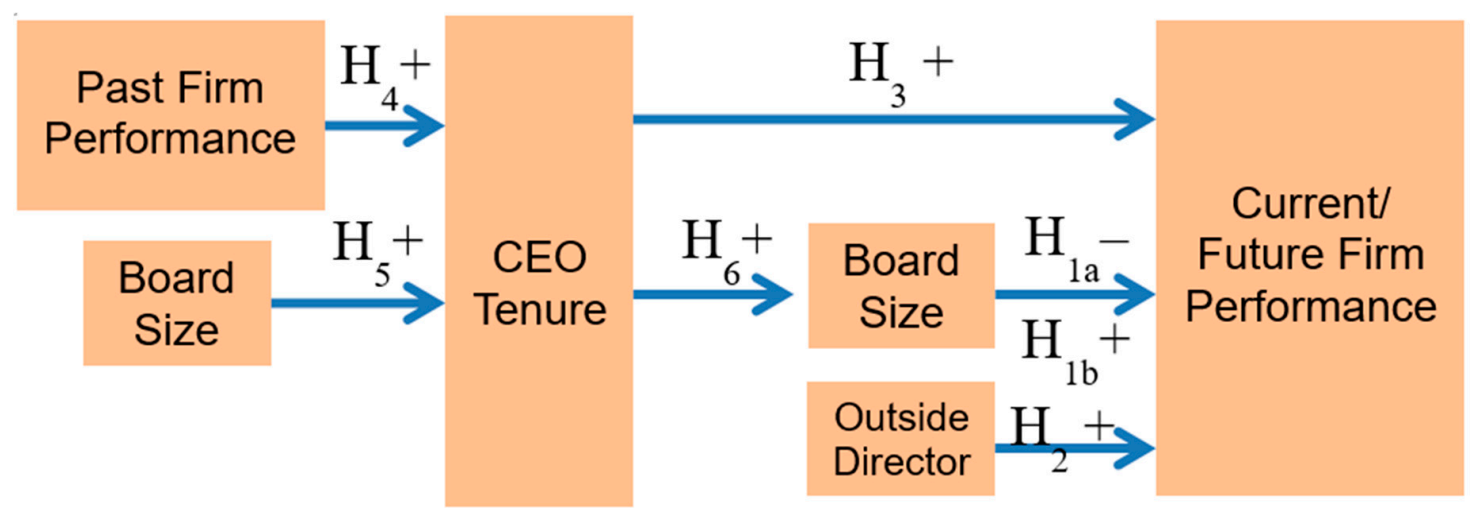

Figure 1. Conceptual model of endogeneity of cooperative governance and performance. (Note: Adaptation of Hermalin and Weisbach's (2003) model of corporate governance literature).

\subsection{Board Size}

Efforts to determine optimal board size weigh tradeoffs between further insights and expertise of additional directors and increasing transaction costs of involving more directors in decision making [25]. According to Hermalin and Weisbach's [19] review of early corporate governance literature, "one of the most consistent empirical relationships regarding boards of directors is that board size is negatively related to firm profitability." The evidence is consistent with agency theorists' assertion that smaller boards, as more effective monitors, enhance performance $[26,27]$. These claims are supported by theories of collective action and agent modeling [28,29]. Large boards also may allow little time for each director to voice opinions, hindering coordination and communication and resulting in slow decision making or inaction and may lead to diffusion of responsibility, instigating second order free riding [30-34]. A survey by Lang [35] suggests that this negative relationship may also hold for cooperatives: "some respondents observed that reduction in board size has made it possible for members to be more selective in voting for directors and led to greater accountability, less anonymity and more efficient board meetings." Hence, we hypothesize:

Hypothesis 1a. Smaller boards improve performance.

However, cooperatives may benefit from having relatively larger boards to perform representational and legitimizing democratic functions. Cooperatives are dependent upon patron-members for competitive performance. Resource dependency theory offers a contingency model, where firms that are highly dependent on external actors benefit from larger networks and greater access to information afforded by larger boards [36]. Thus, co-opting board members representative of the patron group may allow cooperatives to reduce external dependency and gain valuable patron information. To successfully manage diverse patron-cooperative interdependencies, cooperative boards may require a larger, representational body. Hence, we also propose:

Hypothesis 1b. Larger boards improve performance.

\subsection{Board Composition}

According to Hermalin and Weisbach [19], the most widely discussed question about boards is whether including more outside (i.e., non-employee) directors improves corporate performance. Corporate governance literature again emphasizes the board's role in monitoring the CEO, noting that outside directors have greater monitoring incentives than inside (employee) directors who may owe their position to the CEO.

The inclusion of industry experts on the cooperative board of directors, which is conventionally composed entirely of patron-members, is one of the relatively recent evolutions in cooperative 
governance discussed by academics [24]. In cooperatives, however, the influence of these outside directors on performance may be more reflective of additional industry expertise than incentives to monitor the CEO. As noted above, most cooperative directors are user members, chosen democratically for representational purposes [37]. These individuals often possess much more expertise in production agriculture than in downstream industry activities. Hence, in the case of U.S. agricultural cooperatives, adding one or more outside directors whose skills complement those on the board and granting those outside directors voting rights may help lead the cooperative in more productive directions [35]. Dunn's [38] survey indicates that board meetings involving outside directors tend to stay on topic and run smoother and outside directors may bring objectivity to a board that otherwise has problems with conflicts of interest. Arguably, inclusion of outside experts on the board can strengthen the market position and thereby, the sustainability of the cooperative [24]. Therefore, we hypothesize:

Hypothesis 2. Including outside directors improves performance.

\subsection{CEO Tenure}

Little research on cooperative governance examines the relationships between CEOs and cooperative performance. Liang and Hendrikse [39] consider the relative efficiency of cooperative member CEOs and outside CEOs. The study finds that cooperative member CEOs are efficient if upstream and downstream activities are complements or in cases of substitutes if the substitution effect is sufficiently small or large and/or the difference in marginal productivity of those activities is sufficiently large. Following the management literature, we consider how managerial experience and firm-specific expertise that comes with experience at a particular firm may lead to better decision making and direction of the firm $[40,41]$. Therefore, we hypothesize:

Hypothesis 3. Longer CEO tenure improves performance.

\subsection{Endogenous Effects}

Much of the endogeneity issues surrounding corporate governance research involve the power struggle between the board and the CEO and the impact of past performance on the relative balance of power [19]. As already noted, a primary board responsibility is choosing, monitoring and possibly, replacing the CEO $[42,43]$ and smaller boards are considered more effective in this regard. In Hermalin and Weisbach's [19] model, firm performance is the primary metric the board considers when deciding to retain or replace the CEO and "the negative relationship between performance and CEO turnover is extremely robust" [19]. Hence, we hypothesize:

Hypothesis 4. Poor past firm performance leads to shorter CEO tenure.

Hypothesis 5. Smaller boards are better monitors leading to shorter CEO tenure.

Hermalin and Weisbach $[19,44,45]$ emphasize that, within economics, corporate governance has long been viewed through the lens of agency with the board's primary responsibility being to monitor managers who may behave at odds with the desires of its principals (e.g., shareholders or in the case of a cooperative, patron-members). Hence, managers can be expected to influence how they will be observed and by whom. CEOs of well performing IOFs gain bargaining power and are able to add more directors to the board that owe their career success to the CEO [46]. If larger boards are less vigilant, a successful CEO will bargain to increase the size of his board [47]. These additions may increase board size, which the CEO may prefer, since as discussed above, smaller boards are viewed as more effective monitors [26,27]. As CEO tenure is indicative of bargaining power [48], we hypothesize:

Hypothesis 6. Longer CEO tenure leads to larger boards. 
However, in a cooperative the CEO usually has significantly less influence over who sits on the board. While management may recommend people to fill outside director seats, patron-members democratically control the selection and retention of outside directorships through voting [38]. Empirical work by Cook and Burress [49] finds that experienced cooperative CEOs (i.e., tenure $>10$ years) are unable to significantly influence board composition likely due to limited formal avenues for such actions in cooperatives, but they may negotiate more lenient monitoring through procedural and formal committee aspects of board governance. Hence, given the cooperative CEO's limited ability to influence board size, support for Hypothesis 6 may be less likely than in the context of IOFs.

\subsection{Implications of Recent Work}

Several of the empirical regularities identified by Hermalin and Weisbach [19] do not appear to hold true, once endogeneity is properly accounted for. Generally, the significant effects of board size and independence/composition (i.e., outside directors) do not persist, once the impacts of past performance on these variables is taken into account. Below, we provide brief summaries of studies addressing the endogeneity issue in the corporate governance literature.

Bhagat and Black [20] address endogeneity of board independence and financial performance of American firms using three stage least squares (3SLS). Their results suggest that firms suffering from low profitability respond by increasing board independence but provide no evidence that independent boards achieve superior profitability. In fact, independence and board size have either insignificant or negative effects on subsequent performance, depending on performance measure employed.

Pham, Suchard and Zein [21] and Wintoki, Linck and Netter [23] utilize panel data and a generalized method of moments procedure to account for endogeneity of board independence, board size, and firms' financial performance. Upon accounting for endogeneity, neither study finds these board characteristics to impact financial performance, though Wintoki, Linck and Netter [23] find past performance has a negative impact on board independence and a positive effect on board size.

Burress, Cook and O'Brien [5] and Bond (2009) provide the only available insights regarding the extent to which findings of corporate governance research pertain to cooperatives. Burress, Cook and $\mathrm{O}^{\prime} \mathrm{Brien}$ [5] find some evidence that smaller boards with outside directors granted voting rights perform better. Similarly, Bond (2009) finds that additional board members do eventually reduce some measures of performance. In light of the findings of recent corporate governance research, it is appropriate to revisit the issue of cooperative governance, controlling for potential endogeneity not addressed in prior work.

\section{Materials and Methods}

To investigate whether findings of corporate governance research are applicable to cooperatives, we test the above hypotheses using U.S. cooperative data from two sources. Financial performance data are obtained from the U.S. Department of Agriculture (USDA) Cooperative Statistics database. All other variables are derived from a mail survey conducted in 2010. The sample frame consists of 2252 U.S. farmer, rancher and fishery cooperatives listed in the USDA Cooperative Statistics database, of which the top 1000 constitute over $90 \%$ of U.S. agricultural cooperative business volume. Thus, we survey the top 1000 cooperatives, maintaining proportions by function similar to those of the population, as represented by the portion of 2009 revenue is attributed to marketing, supply or service sales receipts. This delineation classifies $529(53 \%)$ as marketing cooperatives, $412(41 \%)$ as supply cooperatives and $59(6 \%)$ as service cooperatives.

Given limited resources, we survey board chairs. Board chairs are likely to have a longer tenure relative to other directors. In addition, chairs are often selected by their peers. Their leadership position and organizational memory provide a well-informed perspective. Of the 460 survey responses received, the majority are from marketing cooperatives (56\%) followed by supply cooperatives $(42 \%)$ and service cooperatives ( $2 \%)$. With available financial data and accounting for incomplete surveys, 
the sample available for analysis is 427 observations for the model including responses on outside directors and 442 observations for the simpler model omitting that variable.

\subsection{Performance Measures}

We develop measures of financial performance from USDA Cooperative Statistics, including an extra-value index $(E V I)$, return on assets $(R O A)$, return on equity $(R O E)$ and scale/factor measures of performance from survey responses [50-52]. EVI is useful for evaluating cooperative performance because it attempts to quantify opportunity costs of member equity capital and deduct this cost from the profitability ratio [50,52]. Survey respondents also rate their cooperative's overall performance on a scale from one (equals "poor") to ten (equals "excellent") [53]. Table 1 provides summary statistics for these performance variables along with measures of CEO and board characteristics and control variables discussed below. Financial performance varies considerably across firms, as indicated by maximum and minimum statistics and standard deviations and in terms of mean values across years and some financial measures (i.e., $R O E$ ) vary more than others.

Table 1. Summary Statistics.

\begin{tabular}{|c|c|c|c|c|c|}
\hline Variable & Observations & Mean & $\begin{array}{c}\text { Standard } \\
\text { Deviation }\end{array}$ & Minimum & Maximum \\
\hline \multicolumn{6}{|l|}{ Performance Measures: } \\
\hline EVI_2006 & 454 & $3.71 \%$ & $12.86 \%$ & $-45.00 \%$ & $174.00 \%$ \\
\hline EVI_2007 & 458 & $7.22 \%$ & $10.92 \%$ & $-19.00 \%$ & $94.00 \%$ \\
\hline ROA_2005 & 454 & $7.09 \%$ & $28.75 \%$ & $-19.00 \%$ & $605.00 \%$ \\
\hline ROA_2006 & 454 & $5.92 \%$ & $5.96 \%$ & $-19.00 \%$ & $39.00 \%$ \\
\hline ROA_2007 & 458 & $7.43 \%$ & $6.81 \%$ & $-11.00 \%$ & $45.00 \%$ \\
\hline ROA_2008 & 460 & $8.26 \%$ & $7.15 \%$ & $-18.00 \%$ & $62.00 \%$ \\
\hline ROA_2009 & 460 & $8.10 \%$ & $9.35 \%$ & $-52.00 \%$ & $104.00 \%$ \\
\hline ROE_2008 & 460 & $20.70 \%$ & $30.18 \%$ & $-503.00 \%$ & $128.00 \%$ \\
\hline ROE_2009 & 460 & $18.00 \%$ & $42.28 \%$ & $-503.00 \%$ & $522.00 \%$ \\
\hline Overall Performance ${ }^{a}$ & 458 & 8.18 & 1.39 & 2.00 & 10.00 \\
\hline \multicolumn{6}{|l|}{ Cooperative Characteristics: } \\
\hline Employees & 460 & 195.08 & 641.33 & 0.00 & 9738.50 \\
\hline CEO Tenure & 451 & 10.40 & 8.66 & 0.50 & 50.00 \\
\hline Board Size & 456 & 9.07 & 4.23 & 5.00 & 51.00 \\
\hline Outside Director (=1 if outside voter) & 459 & 0.02 & 0.15 & 0.00 & 1.00 \\
\hline
\end{tabular}

${ }^{a}$ Respondents rated their cooperatives on a scale from $1=$ poor to $10=$ excellent.

\subsection{Control Measures}

To facilitate inference of the specific effects of CEO and board characteristics on cooperative performance, control variables are included in the regression analysis. The natural logarithm of the number of employees is included to control for cooperative size. Additionally, industry dummies developed from USDA Cooperative Statistics industry classifications control for industry effects.

\subsection{Measures of Board and CEO Characteristics}

Survey responses allow for measurement of constructs regarding board and CEO characteristics, which can be compared with statistics on IOFs from the 2010 Spencer Stuart Board Index [54]. Specifically, we consider CEO Tenure at the cooperative in that capacity, which averages 10.40 years in our sample (Table 1) compared to 15.50 years in corporations. Components of board structure 
considered here include board size and whether it includes outside (non-patron-member) directors. Board Size is the total number of board members, which averages nine for our sample (Table 1). Outside Director equals one if at least one independent, non-patron director serves on the board and is extended voting rights. Four percent of cooperatives in our survey have outside directors and only half of those (two percent) extend voting rights to outside directors (Table 1). In comparison, corporate boards are larger with 11 members on average and have greater outsider presence with a 3:1 ratio of outsiders to insiders.

\subsection{Model}

We address the possible endogeneity of board and CEO characteristics and firm performance using three stage least squares (3SLS) estimation, as described in Zellner and Theil [55]. This method combines the consistency of two stage least squares (2SLS) with the asymptotic efficiency of seemingly unrelated regression (SUR) by accounting for across equation correlation of errors. Each equation is estimated at once instead of separately as in 2SLS. 3SLS is a full information method, as it utilizes all the restrictions in the system when estimating structural parameters. 3SLS is consistent and in general, asymptotically more efficient than 2SLS [56]. In practice, when specifying estimation equations in 3SLS, one must heed the order condition for identification requiring the exclusion of at least as many exogenous variables as the number of endogenous variables included in a particular equation [57].

\section{Results}

\subsection{Correlations}

Notable correlation in performance exists across both measures and years (Table 2). Within a particular year, correlations across financial measures reach as high as 0.98 (e.g., ROE and ROA in 2005) but are somewhat more modest over time-usually a little less than 0.60 . As an exception, correlation between ROE in 2008 and 2009 is 0.75 . Smaller positive correlations exist between Overall Performance and financial performance measures.

Correlations between performance measures and all remaining variables are fairly small (Table 2), suggesting that much of the variation in performance is likely due to unaccounted for factors. $C E O$ Tenure is positively correlated with most measures of current and past performance. Though still weak, the relation between CEO Tenure and Overall Performance is stronger than with other performance measures. Board Size is negatively correlated with most financial measures but positively correlated with Overall Performance. The negative relationships with current values are consistent with the bulk of the corporate governance literature, while the positive relationships may be consistent with greater representation of cooperative members' interests.

Somewhat stronger correlations are apparent between firm and board characteristics (Table 2). These statistics indicate that larger cooperatives have larger boards with more outside directors. Correlations between CEO Tenure, LN(Employees) and each board trait are small and negative. 
Table 2. Correlations.

\begin{tabular}{|c|c|c|c|c|c|c|c|c|c|c|c|c|c|c|c|c|c|c|c|c|c|}
\hline & & 1 & 2 & 3 & 4 & 5 & 6 & 7 & 8 & 9 & 10 & 11 & 12 & 13 & 14 & 15 & 16 & 17 & 18 & 19 & 20 \\
\hline 1 & CEO Tenure & 1.00 & & & & & & & & & & & & & & & & & & & \\
\hline 2 & LN(Employees) & -0.04 & 1.00 & & & & & & & & & & & & & & & & & & \\
\hline 3 & Board Size & -0.04 & 0.50 & 1.00 & & & & & & & & & & & & & & & & & \\
\hline 4 & Outside Director & -0.06 & 0.21 & 0.18 & 1.00 & & & & & & & & & & & & & & & & \\
\hline 5 & Overall Performance & 0.24 & 0.06 & 0.05 & 0.04 & 1.00 & & & & & & & & & & & & & & & \\
\hline 6 & ROA_2009 & 0.01 & -0.07 & -0.07 & -0.04 & 0.14 & 1.00 & & & & & & & & & & & & & & \\
\hline 7 & ROA_2008 & 0.14 & -0.02 & -0.05 & 0.00 & 0.21 & 0.28 & 1.00 & & & & & & & & & & & & & \\
\hline 8 & ROA_2007 & 0.05 & -0.06 & -0.03 & -0.04 & 0.13 & 0.24 & 0.59 & 1.00 & & & & & & & & & & & & \\
\hline 9 & ROA_2006 & 0.12 & 0.01 & 0.01 & -0.05 & 0.15 & 0.08 & 0.37 & 0.58 & 1.00 & & & & & & & & & & & \\
\hline 10 & ROA_2005 & -0.04 & -0.06 & -0.05 & -0.02 & 0.06 & -0.03 & 0.02 & 0.04 & 0.08 & 1.00 & & & & & & & & & & \\
\hline 11 & ROE_2009 & 0.02 & 0.01 & -0.01 & -0.01 & 0.13 & 0.52 & 0.15 & 0.12 & 0.08 & 0.04 & 1.00 & & & & & & & & & \\
\hline 12 & ROE_2008 & 0.10 & -0.01 & -0.01 & 0.01 & 0.17 & 0.16 & 0.45 & 0.25 & 0.18 & 0.06 & 0.75 & 1.00 & & & & & & & & \\
\hline 13 & ROE_2007 & 0.07 & -0.02 & -0.03 & -0.03 & 0.10 & 0.22 & 0.45 & 0.75 & 0.40 & 0.00 & 0.27 & 0.42 & 1.00 & & & & & & & \\
\hline 14 & ROE_2006 & 0.05 & -0.06 & -0.04 & -0.02 & 0.10 & 0.08 & 0.18 & 0.27 & 0.63 & 0.03 & 0.14 & 0.24 & 0.45 & 1.00 & & & & & & \\
\hline 15 & ROE_2005 & -0.05 & -0.06 & -0.05 & -0.01 & 0.03 & -0.04 & -0.05 & -0.05 & -0.05 & 0.98 & 0.03 & 0.03 & -0.06 & -0.05 & 1.00 & & & & & \\
\hline 16 & EVI_2009 & -0.02 & -0.11 & -0.08 & -0.04 & 0.17 & 0.80 & 0.13 & 0.11 & 0.05 & -0.03 & 0.62 & 0.27 & 0.20 & 0.14 & -0.03 & 1.00 & & & & \\
\hline 17 & EVI_2008 & 0.08 & -0.10 & -0.05 & 0.03 & 0.21 & 0.15 & 0.67 & 0.35 & 0.26 & 0.01 & 0.27 & 0.61 & 0.52 & 0.39 & -0.03 & 0.33 & 1.00 & & & \\
\hline 18 & EVI_2007 & 0.05 & -0.11 & -0.05 & -0.04 & 0.12 & 0.20 & 0.47 & 0.77 & 0.45 & 0.00 & 0.17 & 0.35 & 0.91 & 0.53 & -0.07 & 0.19 & 0.57 & 1.00 & & \\
\hline 19 & EVI_2006 & 0.06 & -0.07 & -0.03 & -0.02 & 0.10 & 0.01 & 0.16 & 0.26 & 0.62 & 0.01 & 0.09 & 0.24 & 0.49 & 0.86 & -0.05 & 0.11 & 0.46 & 0.62 & 1.00 & \\
\hline 20 & EVI_2005 & -0.06 & -0.07 & -0.05 & -0.01 & 0.04 & -0.04 & -0.03 & -0.03 & -0.02 & 0.98 & 0.02 & 0.05 & -0.03 & -0.03 & 0.99 & -0.06 & 0.00 & -0.04 & -0.04 & 1.00 \\
\hline
\end{tabular}




\subsection{Factor Analysis}

The level of correlation among performance measures justifies use of factor analysis to develop a more parsimonious set of variables (i.e., eigenvectors, also called factors) that capture the relevant variation of this larger set [18]. Using this approach, Franken and Cook [17] demonstrate that board chairs' responses to a survey item on overall cooperative performance adequately reflects financial performance (i.e., financial data acquired from the USDA) and other aspects of performance (i.e., survey responses on competitive position, patron satisfaction and vision achievement). We revisit the analysis relating just the financial measures (i.e., ROA, ROE and EVI) to the survey item on Overall Performance. As shown in Figure 2, the coefficients for the analysis using this subset of the original data, shown in bold, correspond fairly closely to the coefficients from the original analysis. For instance, since we only consider how well Financial Performance reflects Overall Performance, the coefficient 0.17 actually reflects the direct relationship between these two variables, which is nearly identical to the combined effects of coefficients between Financial Performance, Overall Profitability and Overall Performance in Franken and Cook's original model $(0.22 \times 0.80=0.176)$. All other coefficients are directly comparable across models. The fit statistics imply that together the three financial statistics also provide a reasonably accurate indicator of Overall Performance. For the root mean squared error (RMSE), a value below 0.08 indicates a close fit [58], while a value greater than 0.90 is recommended for the Tucker-Lewis Index (TLI) [59]. Using these relationships and the historical data we have available for $R O A, R O E$ and $E V I$, we are able to infer past levels of Overall Performance, enabling analysis of this variable within the 3SLS framework to account for endogeneity.

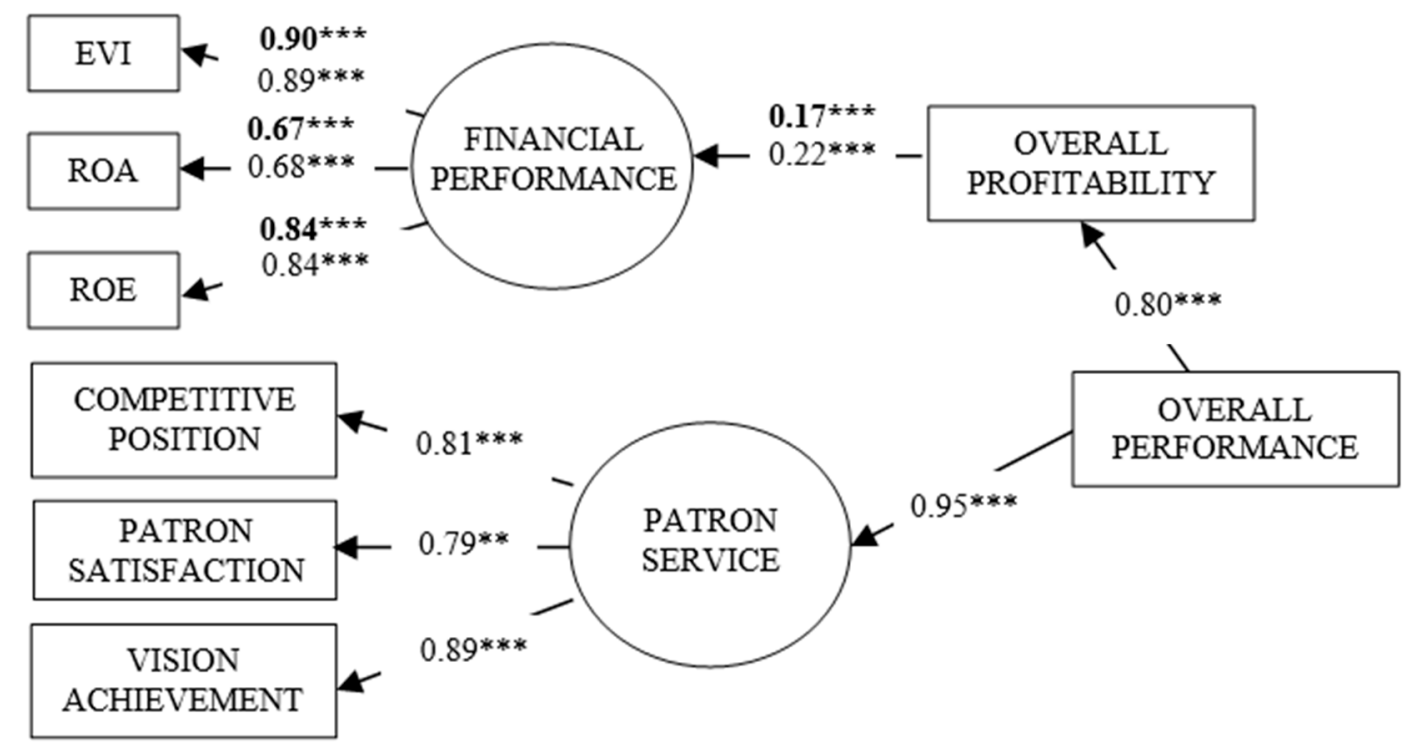

Figure 2. Franken and Cook's [17] confirmatory factor analysis and analysis of a subset of data. Note: Coefficients from original model shown along with bolded coefficients for the partial model. Original Model: RMSE $=0.059, \mathrm{TLI}=0.976$. Partial Model: $\mathrm{RMSE}=0.016, \mathrm{TLI}=0.998$. Significance levels (two-tailed): ${ }^{* * *} p<0.01$.

\subsection{Regression Results}

Three stage least squares (3SLS) regressions are used to control for endogeneity, while investigating impacts of board structure on four measures of performance. 3SLS estimation combines system equation, sometimes known as seemingly unrelated regression (SUR), with two-stage least squares (2SLS) estimation [60]. It is a type of instrumental variables estimation that permits correlations of unobserved disturbances (i.e., errors) across several equations and improves upon the efficiency of equation-by-equation estimation by taking account of such correlation. Unlike 2SLS, which estimates the coefficients of each equation separately, 3SLS estimates all coefficients simultaneously. Due to high 
correlation in annual performance, some corporate governance studies sample performance every 3 years to avoid multicollinearity [61-63]. However, Wintoki, Linck and Netter [23] find inferences regarding the relation between corporate governance and performance are insensitive to sampling every year or every three years. As correlations of performance measures over time in our data (Table 2) are usually less than common rules of thumb indicative of multicollinearity (e.g., greater than 0.70 or 0.80 ), we proceed by including each past value of a particular performance measure as explanatory variables in the CEO tenure equation [64]. In the Overall Performance model, the lagged values are computed from past values of financial data based on the factor analysis reported above.

Regression coefficients for the full model are presented in Table 3. As a sensitivity analysis, fairly similar results are reported in Table 4 for a model that excludes the Outside Director variable, since relatively few of these directors exist in the sample. In the interest of space, coefficients on industry dummy variables are not reported. $R^{2}$ may be negative in 3SLS models, since errors are computed over a different set of regressors than that used to fit the model and reporting the statistic is a matter of taste as it has no statistical meaning in this context [65]. Instead, we report Wald tests that generally reject the null hypothesis that predictor coefficients are not significantly different from zero at the $10 \%$ level or better. The null cannot be rejected for performance equations in EVI and ROE models reported in Table 3. These results reflect the difficulty in measuring cooperative performance solely with financial statistics.

Table 3. Results of Three Stage Least Squares Regressions of Performance on Governance, Including Outside Director Variable.

\begin{tabular}{|c|c|c|c|c|}
\hline Performance & EVI Model & ROE Model & ROA Model & Overall Performance \\
\hline LN(Employees) & $\begin{array}{c}0.015 \\
(0.256)\end{array}$ & $\begin{array}{c}0.108 \\
(1.077)\end{array}$ & $\begin{array}{l}0.239 * \\
(0.124)\end{array}$ & $\begin{array}{l}2.285^{*} \\
(1.215)\end{array}$ \\
\hline CEO Tenure & $\begin{array}{c}0.032 \\
(0.025)\end{array}$ & $\begin{array}{c}0.164 \\
(0.151)\end{array}$ & $\begin{array}{c}0.018^{* * *} \\
(0.005)\end{array}$ & $\begin{array}{c}0.097 \\
(0.120)\end{array}$ \\
\hline Board Size & $\begin{array}{l}-0.035 \\
(0.070)\end{array}$ & $\begin{array}{c}-0.549 * \\
(0.301)\end{array}$ & $\begin{array}{c}-0.058^{*} \\
(0.031)\end{array}$ & $\begin{array}{c}-0.890^{* * * *} \\
(0.334)\end{array}$ \\
\hline Outsider Director & $\begin{array}{c}0.803 \\
(0.585)\end{array}$ & $\begin{array}{c}15.060^{* * *} \\
(5.172)\end{array}$ & $\begin{array}{l}-0.315 \\
(0.301)\end{array}$ & $\begin{array}{l}7.806^{* *} \\
(3.518)\end{array}$ \\
\hline Constant & $\begin{array}{c}0.059 \\
(0.417)\end{array}$ & $\begin{array}{c}2.837 \\
(2.506)\end{array}$ & $\begin{array}{c}0.018 \\
(0.103)\end{array}$ & $\begin{array}{c}11.012^{* * *} \\
(2.152)\end{array}$ \\
\hline$\chi^{2}$ Statistic & 26.730 & 12.990 & $46.570^{* * *}$ & $31.350 * *$ \\
\hline $\begin{array}{c}p \text {-value } \\
\text { CEO Tenure }\end{array}$ & 0.111 & 0.839 & 0.000 & 0.037 \\
\hline Performance05 & $\begin{array}{l}-0.326 \\
(0.359)\end{array}$ & $\begin{array}{l}-0.044 \\
(0.050)\end{array}$ & $\begin{array}{l}-2.258 \\
(1.405)\end{array}$ & $\begin{array}{l}-0.001 \\
(0.001)\end{array}$ \\
\hline Performance06 & $\begin{array}{l}-1.400 \\
(2.592)\end{array}$ & $\begin{array}{l}-1.552 \\
(1.473)\end{array}$ & $\begin{array}{c}2.574 \\
(7.442)\end{array}$ & $\begin{array}{c}0.008 \\
(0.014)\end{array}$ \\
\hline Performance07 & $\begin{array}{c}1.297 \\
(3.571)\end{array}$ & $\begin{array}{c}2.760 \\
(2.988)\end{array}$ & $\begin{array}{c}5.903 \\
(6.686)\end{array}$ & $\begin{array}{l}-0.009 \\
(0.018)\end{array}$ \\
\hline Performance08 & $\begin{array}{l}8.196 \text { ** } \\
(3.969)\end{array}$ & $\begin{array}{l}3.186 \text { ** } \\
(1.396)\end{array}$ & $\begin{array}{l}21.901 * * * \\
(7.329)\end{array}$ & $\begin{array}{l}0.036^{* *} \\
(0.015)\end{array}$ \\
\hline Board Size & $\begin{array}{l}-0.181 \\
(0.175)\end{array}$ & $\begin{array}{l}-0.208 \\
(0.174)\end{array}$ & $\begin{array}{l}-0.140 \\
(0.173)\end{array}$ & $\begin{array}{l}-0.190 \\
(0.174)\end{array}$ \\
\hline Constant & $\begin{array}{c}10.983^{* * *} \\
(1.705)\end{array}$ & $\begin{array}{c}11.295^{* * *} \\
(1.743)\end{array}$ & $\begin{array}{c}9.348^{* * *} \\
(1.742)\end{array}$ & $\begin{array}{c}10.978^{* * * *} \\
(1.732)\end{array}$ \\
\hline $\begin{array}{c}\chi^{2} \text { Statistic } \\
p \text {-value }\end{array}$ & $\begin{array}{c}18.030 * * * \\
0.003\end{array}$ & $\begin{array}{c}49.400^{* * * *} \\
0.000\end{array}$ & $\begin{array}{c}36.150^{* * * *} \\
0.000\end{array}$ & $\begin{array}{c}10.040 \text { * } \\
0.074\end{array}$ \\
\hline Board Size & & & & \\
\hline LN(Employees) & $\begin{array}{c}3.449 * * * \\
(0.352)\end{array}$ & $\begin{array}{c}3.463^{* * *} \\
(0.333)\end{array}$ & $\begin{array}{c}3.489^{* * *} \\
(0.314)\end{array}$ & $\begin{array}{c}3.449^{* * *} \\
(0.328)\end{array}$ \\
\hline CEO Tenure & $\begin{array}{l}-0.015 \\
(0.200)\end{array}$ & $\begin{array}{c}0.003 \\
(0.160)\end{array}$ & $\begin{array}{c}0.044 \\
(0.102)\end{array}$ & $\begin{array}{l}-0.016 \\
(0.149)\end{array}$ \\
\hline
\end{tabular}


Table 3. Cont.

\begin{tabular}{ccccc}
\hline Performance & EVI Model & ROE Model & ROA Model & Overall Performance \\
\hline Constant & 3.031 & 2.819 & $2.356^{*}$ & 3.036 \\
& $(2.479)$ & $(2.005)$ & $(1.353)$ & $(1.887)$ \\
$\chi^{2}$ Statistic & $214.420^{* * *}$ & $214.480^{* * *}$ & $211.960^{* * *}$ & $214.420 * * *$ \\
$p$-value & 0.000 & 0.000 & 0.000 & 0.000 \\
Outside Director & & & & \\
LN(Employees) & $0.135^{* * *}$ & $0.127^{* * *}$ & $0.126^{* * *}$ & $0.132 * * *$ \\
& $(0.038)$ & $(0.034)$ & $(0.032)$ & $(0.034)$ \\
CEO Tenure & 0.014 & 0.002 & 0.001 & 0.010 \\
& $(0.022)$ & $(0.016)$ & $(0.010)$ & $(0.016)$ \\
Constant & -0.353 & -0.221 & -0.204 & -0.311 \\
& $(0.269)$ & $(0.204)$ & $(0.136)$ & $(0.198)$ \\
$\chi^{2}$ Statistic & $28.790^{* *}$ & $30.340^{* *}$ & $30.430 * *$ & $29.670 * *$ \\
$p$-value & 0.037 & 0.024 & 0.023 & 0.029 \\
\hline
\end{tabular}

Note: $N=427 .{ }^{*}, * *, * * *$ denote statistical significance at $10 \%, 5 \%, 1 \%$. Standard errors in parentheses.

Table 4. Results of Three Stage Least Squares Regressions of Performance on Governance, Excluding Outside Director Variable.

\begin{tabular}{|c|c|c|c|c|}
\hline Performance & EVI Model & ROE Model & ROA Model & Overall Performance \\
\hline \multirow[t]{2}{*}{ LN(Employees) } & 0.126 & 0.897 & 0.121 & $2.525^{* * *}$ \\
\hline & $(0.207)$ & $(0.895)$ & $(0.087)$ & $(0.952)$ \\
\hline \multirow[t]{2}{*}{ CEO Tenure } & 0.0420 * & $0.1778^{* *}$ & $0.0151^{* * *}$ & 0.1035 \\
\hline & $(0.024)$ & $(0.075)$ & $(0.005)$ & $(0.088)$ \\
\hline \multirow[t]{2}{*}{ Board Size } & -0.037 & -0.239 & -0.037 & $-0.681^{* *}$ \\
\hline & $(0.062)$ & $(0.263)$ & $(0.025)$ & $(0.279)$ \\
\hline \multirow[t]{2}{*}{ Constant } & -0.199 & -1.094 & 0.050 & 8.852 \\
\hline & $(0.389)$ & $(1.287)$ & $(0.103)$ & $(1.546)$ \\
\hline \multirow{2}{*}{$\begin{array}{c}\chi^{2} \text { Statistic } \\
p \text {-value }\end{array}$} & $49.600^{* * *}$ & $64.120^{* * *}$ & $47.860^{* * *}$ & $45.470^{* * *}$ \\
\hline & 0.000 & 0.000 & 0.000 & 0.000 \\
\hline \multicolumn{5}{|l|}{ CEO Tenure } \\
\hline \multirow[t]{2}{*}{ Performance05 } & -0.233 & -0.024 & -1.454 & $4.7 \times 10^{-4}$ \\
\hline & $(0.357)$ & $(0.048)$ & $(1.338)$ & $(0.001)$ \\
\hline \multirow[t]{2}{*}{ Performance06 } & -1.011 & -0.700 & 5.387 & 0.009 \\
\hline & $(2.349)$ & $(1.567)$ & $(6.707)$ & $(0.014)$ \\
\hline \multirow[t]{2}{*}{ Performance07 } & 0.701 & -0.517 & 8.425 & -0.008 \\
\hline & $(2.040)$ & $(1.029)$ & $(5.655)$ & $(0.016)$ \\
\hline \multirow[t]{2}{*}{ Performance08 } & $8.854^{* * *}$ & $4.743^{* * *}$ & $18.485^{* * *}$ & $0.037^{* * *}$ \\
\hline & $(2.338)$ & $(0.836)$ & $(5.965)$ & $(0.012)$ \\
\hline \multirow[t]{2}{*}{ Board Size } & -0.109 & -0.131 & -0.079 & -0.117 \\
\hline & $(0.163)$ & $(0.162)$ & $(0.161)$ & $(0.162)$ \\
\hline \multirow[t]{2}{*}{ Constant } & $10.345^{* * *}$ & $10.792^{* * *}$ & $8.718^{* * *}$ & $10.311^{* * *}$ \\
\hline & $(1.586)$ & (1.613) & (1.639) & (1.619) \\
\hline \multirow{2}{*}{$\begin{array}{c}\chi^{2} \text { Statistic } \\
p \text {-value }\end{array}$} & $27.770^{* * *}$ & $110.380^{* * *}$ & $37.480 * * *$ & $10.990^{* * *}$ \\
\hline & 0.000 & 0.000 & 0.000 & 0.052 \\
\hline \multicolumn{5}{|l|}{ Board Size } \\
\hline \multirow[t]{2}{*}{ LN(Employees) } & $3.410^{* * *}$ & $3.452 * * *$ & $3.446^{* * *}$ & $3.420^{* * *}$ \\
\hline & $(0.343)$ & $(0.324)$ & $(0.308)$ & $(0.324)$ \\
\hline \multirow[t]{2}{*}{ CEO Tenure } & -0.119 & -0.037 & -0.047 & -0.101 \\
\hline & (0.197) & $(0.156)$ & $(0.099)$ & $(0.148)$ \\
\hline \multirow[t]{2}{*}{ Constant } & $4.175^{*}$ & 3.258 * & $3.344^{* * *}$ & $3.978 * *$ \\
\hline & $(2.419)$ & $(1.951)$ & $(1.304)$ & $(1.854)$ \\
\hline$\chi^{2}$ Statistic & $223.190^{* * *}$ & $239.130^{* * *}$ & $239.370^{* * *}$ & $228.350 * * *$ \\
\hline$p$-value & 0.000 & 0.000 & 0.000 & 0.000 \\
\hline
\end{tabular}

Note: $N=442 .{ }^{*}, * *, * * *$ denote statistical significance at $10 \%, 5 \%, 1 \%$. Standard errors in parentheses. 
Regression coefficients in Table 3 offer some evidence of better performance by cooperatives with smaller boards (Hypothesis 1a) and outside voting directors (Hypothesis 2). Board Size and Outside Director, respectively, have significantly negative and positive effects on Overall Performance, as well as on some financial measures. For instance, decreasing board size by one director, on average, increases $R O A$ about $6 \%$. Similarly, the positive impact of CEO Tenure on ROA supports Hypothesis 3 , indicating about a $2 \%$ increase in $R O A$ with each additional year of tenure, on average. Significantly positive coefficients on $L N$ (Employees) in the ROA and Overall Performance models may indicate economies of scale. An anonymous reviewer notes that, in addition to this positive impact on performance, $L N$ (Employees) also has a significantly positive effect on Board Size, which has a significantly negative impact on performance. That is, the optimal board size for larger cooperatives is likely larger than that of smaller cooperatives but for any particular size cooperative it is likely better to constrain rather than expand board size.

Regression coefficients for the CEO Tenure equation in each performance model indicate a significantly positive relationship with performance in 2008, consistent with Hypotheses 4 (Table 3). That is, better (or worse) performance in 2008 leads to significantly longer (or shorter) CEO Tenure. However, inconsistent with Hypotheses 5 and 6, there is no evidence that Board Size influences CEO Tenure or that CEO Tenure influences Board Size. Again, Board Size appears to be driven by the size of the cooperative, that is, $L N$ (Employees), which may reflect more directors being included on the board to represent larger and perhaps, more heterogeneous cooperative membership.

The finding that CEO Tenure does not significantly impact the composition of the cooperative board (i.e., Board Size and Outside Director) is not entirely surprising. In the corporate governance literature, empowered CEOs negotiate less independent boards with fewer outside directors and more inside directors (i.e., management) that owe their career success to the CEO [46]. In cooperatives, the board consists primarily of democratically elected patron members and the CEO's ability to influence board composition is mostly limited to nominating industry experts to serve as outside directors. Such nominees, typically, still must be elected by cooperative members.

\section{Discussion}

Empirical work in the field of corporate governance is extensive but may not be uniformly applicable to cooperative businesses with patron-driven, multiple objective functions [66]. Limited inquiry into the realm of cooperative governance suggests that best practices in corporate governance will not necessarily transfer into superior cooperative performance but does not address the potential endogeneity of governance and performance [5]. Recent work accounting for endogeneity in corporate governance literature effectively overturns several previously established empirical regularities [19], adding further uncertainty regarding likely impacts of governance choices for performance in corporations and cooperatives alike. Here, we attempt to account for some of the more widely recognized endogenous relationships in the corporate governance literature, as we investigate the impacts of governance decisions for the performance of cooperatives. As any one financial performance measure may not clearly indicate the degree to which cooperatives accomplish goals of serving patron-members, we focus on a factor analytic measure of overall performance developed from the common correlation among several financial measures [17].

Three stage least squares regressions and sensitivity analysis with respect to model specification, allow us to infer some consistent results. Namely, larger cooperatives and cooperatives with smaller boards tend to perform better-an empirical regularity for firms in the early corporate governance literature that is unsupported by more recent corporate governance work accounting for endogeneity. An anonymous reviewer identifies that, in addition to these respective positive and negative impacts of cooperative and board size on performance, the size of the cooperative also has a significantly positive effect on that of the board. The implication of these results from a managerial standpoint is that larger cooperatives likely require larger boards to adequately represent the potentially greater heterogeneity of a larger membership, but for any particular size cooperative it is likely better to constrain rather 
than expand board size. Overall, this is consistent with the corporate governance literature's general findings of a negative relationship between board size and performance with the exception of a positive effect for large, diversified firms $[19,23,67]$. Our results also indicate that seating outside directors with industry expertise on the board leads to better overall performance-an inference we make with some caution due to the limited number of outside directors in the sample. A sensitivity analysis, omitting the outside director dummy variable, substantiates that other results are fairly robust. Specifically, smaller boards tend to have better overall performance, and CEO tenure increases with performance, but in contrast to the corporate governance literature, there appears to be no statistically significant link between CEO tenure and board size. This last point may reflect that, unlike corporate boards, the CEO of a cooperative has significantly less influence over who sits on the board, as these decisions are determined democratically by patron-members' votes [38].

This study focuses on key aspects of governance emphasized in the corporate governance literature in order to facilitate comparison. For instance, in accordance with Hermalin and Weisbach's [19] arguments, we use CEO tenure as an indicator of the CEO's power but alternative measures may be considered in future research. Notably, our results are specific to U.S. agriculture cooperatives, and while all cooperatives share some commonalities, future research may re-evaluate our findings for cooperatives in other industries and/or countries. Extensions of this analysis may add board processes identified by Burress, Cook and O'Brien [5] in addition to board composition. Additionally, endogeneity issues associated with anticipated causal relations and path-like effects of past performance on aspects of governance that influence subsequent performance may be further explored using structural equation models [68] and directed acyclic graphs [69-71].

Author Contributions: Formal analysis, J.R.V.F.; Methodology, J.R.V.F.; Project administration, M.L.C.; Resources, M.L.C.; Writing-review \& editing, M.L.C.

Funding: This research received funding from USDA under Cooperative Research Agreement RBS-09-40. We also acknowledge the detailed and enthusiastic responses of survey participants.

Conflicts of Interest: The authors declare no conflicts of interest.

\section{References}

1. Benos, T.; Kalogeras, N.; Wetzels, M.; Ruyter, K.D.; Pennings, J.M. Harnessing a 'currency matrix' for performance measurement in cooperatives: A multi-phased study. Sustainability 2018, 10, 4536. [CrossRef]

2. Grashuis, J. An exploratory study of cooperative survival: Strategic adaptation to external developments. Sustainability 2018, 10, 652. [CrossRef]

3. Cook, M.L. A life cycle explanation of cooperative longevity. Sustainability 2018, 10, 1586. [CrossRef]

4. Bond, J.K. Cooperative Financial Performance and Board of Director Characteristics: A Quantitative Investigation. J. Coop. 2009, 22, 22-44.

5. Burress, M.J.; Cook, M.L.; O'Brien, D.J. Determinants of patron owned entity performance as a function of board characteristics and processes. In Corporate Governace: The Role of the Board of Directors in Understanding and Managing Disruptive and Transformational Technologies; College of Business, University of Missouri: Columbia, MO, USA, 2011.

6. Burress, M.J.; Livingston, K.; Cook, M.L. Board process, board engagement and cooperative health: A descriptive summary of survey findings. Coop. Account. 2012, 65, 16-29.

7. Burress, M.J.; Livingston, K.; Cook, M.L. Cooperative boards: A descriptive summary of survey findings regarding demographics, director development and member engagement. Coop. Account. 2011, 64, 20-30.

8. Grashuis, J. The impact of brand equity on the financial performance of marketing cooperatives. Agribusiness 2019, 35, 234-248. [CrossRef]

9. Kalogeras, N.; Pennings, J.M.; Benos, T.; Doumpos, M. Which Cooperative Ownership Model Performs Better? A Financial-Decision Aid Approach. Agribusiness 2013, 29, 80-95. [CrossRef]

10. Babcock, H. Cooperatives the Pace-Setters in Agriculture. J. Farm Econ. 1935, 17, 153-156. [CrossRef]

11. Nourse, E.G. The place of the cooperative in our national economy. Am. Coop. 1942, 1945, 33-39. 
12. Soboh, R.A.; Lansink, A.O.; Giesen, G.; van Dijk, G. Performance Measurement of the Agricultural Marketing Cooperatives: The Gap Between Theory and Practice. Appl. Econ. Perspect. Policy 2009, 31, 446-469. [CrossRef]

13. LeVay, C. Agricultural Co-operative Theory: A Review. J. Agric. Econ. 1983, 34, 1-44. [CrossRef]

14. Verhofstadt, E.; Maertens, M. Smallholder cooperatives and agricultural performance in Rwanda: Do organizational differences matter? Agric. Econ. 2014, 45, 39-52. [CrossRef]

15. Martínez-Victoria, M.; Maté Sánchez-Val, M.; Arcas-Lario, N. Spatial determinants of productivity growth on agri-food Spanish firms: A comparison between cooperatives and investor-owned firms. Agric. Econ. 2018, 49, 213-223.

16. Karami, E.; Rezaei-Moghaddam, K. Modeling determinants of agricultural production cooperatives' performance in Iran. Agric. Econ. 2005, 33, 305-314. [CrossRef]

17. Franken, J.R.; Cook, M.L. Informing Measurement of Cooperative Performance. In Interfirm Networks; Springer: New York, NY, USA, 2015; pp. 209-226.

18. Thompson, B. Exploratory and Confirmatory Factor Analysis: Understanding Concepts and Applications; American Psychological Association: Washington, DC, USA, 2004.

19. Hermalin, B.E.; Weisbach, M.S. Boards of directors as an endogenously determined institution: A survey of the economic literature. Econ. Policy Rev. 2003, 9, 7-26.

20. Bhagat, S.; Black, B. The Non-Correlation between Board Independence and Long-Term Firm Performance. J. Corp. Law 2002, 27, 231. [CrossRef]

21. Pham, P.; Suchard, J.A.; Zein, J. Corporate governance and alternative performance measures: Evidence from Australian firms. Aust. J. Manag. 2011, 36, 371-386. [CrossRef]

22. Renders, A.; Gaeremynck, A. Corporate Governance and Performance: Controlling for Sample Selection Bias and Endogeneity; KU Leuven AFI Working Paper; KU Leuven: Leuven, Belgium, 2006.

23. Wintoki, M.B.; Linck, J.S.; Netter, J.M. Endogeneity and the dynamics of internal corporate governance. J. Financ. Econ. 2012, 105, 581-606. [CrossRef]

24. Bijman, J.; Hanisch, M.; van der Sangen, G. Shifting control? The changes of internal governance in agricultural cooperatives in the EU. Ann. Public Coop. Econ. 2014, 85, 641-661. [CrossRef]

25. Buchannan, J.; Tullock, G. The Calculus of Consent: Logical Foundations of a Constitutional Democracy; University of Michigan Press: Ann Arbor, MI, USA, 1962.

26. Jensen, M.C. The modern industrial revolution, exit, and the failure of internal control systems. J. Financ. 2012, 48, 831-880. [CrossRef]

27. Yermack, D. Higher market valuation of companies with a small board of directors. J. Financ. Econ. 1996, 40, 185-211. [CrossRef]

28. Klimek, P.; Hanel, R.; Thurner, S. Parkinson's Law quantified: Three investigations on bureaucratic inefficiency. J. Stat. Mech. Theory Exp. 2009, 2009, P03008. [CrossRef]

29. Olson, M.; Olson, M. The Logic of Collective Action: Public Goods and the Theory of Groups; Harvard University Press: Cambridge, MA, USA, 1965; Volume 124.

30. Dalton, D.R.; Daily, C.M.; Johnson, J.L.; Ellstrand, A.E. Number of directors and financial performance: A meta-analysis. Acad. Manag. J. 1999, 42, 674-686.

31. Eisenberg, T.; Sundgren, S.; Wells, M.T. Larger board size and decreasing firm value in small firms. J. Financ. Econ. 1998, 48, 35-54. [CrossRef]

32. Lipton, M.; Lorsch, J.W. A Modest Proposal for Improved Corporate Governance. Bus. Lawyer 1992, 48, 59.

33. Poteete, A.R.; Ostrom, E. Heterogeneity, group size and collective action: The role of institutions in forest management. Dev. Chang. 2004, 35, 435-461. [CrossRef]

34. Yamagishi, T. The provision of a sanctioning system as a public good. J. Personal. Soc. Psychol. 1986, 51, 110. [CrossRef]

35. Lang, M.G. Strengthening Agricultural Cooperatives: An Inquiry into Expert Beliefs; Center for Cooperatives, University of California: Oakland, CA, USA, 2002.

36. Zahra, S.A.; Pearce, J.A., II. Boards of directors and corporate financial performance: A review and integrative model. J. Manag. 1989, 15, 291-334. [CrossRef]

37. Cornforth, C. The governance of cooperatives and mutual associations: A paradox perspective. Ann. Public Coop. Econ. 2004, 75, 11-32. [CrossRef] 
38. Dunn, J.R.; Crooks, A.C.; Frederick, D.A.; Kennedy, T.L.; Wadsworth, J.J. Agricultural Cooperatives in the 21st Century; US Department of Agriculture, Rural Business-Cooperative Service: Washington, DC, USA, 2002; Volume 60.

39. Liang, Q.; Hendrikse, G. Cooperative CEO identity and efficient governance: Member or outside CEO? Agribusiness 2013, 29, 23-38. [CrossRef]

40. Carpenter, M.A.; Westphal, J.D. The strategic context of external network ties: Examining the impact of director appointments on board involvement in strategic decision making. Acad. Manag. J. 2001, 44, 639-660.

41. Taylor, R.N. Age and experience as determinants of managerial information processing and decision making performance. Acad. Manag. J. 1975, 18, 74-81.

42. Mace, M.L. Directors: Myth and Reality; Harvard Business School Press: Boston, MA, USA, 1986.

43. Vancil, R.F. Passing The Baton: Managing The Process of CEO Successi-on; Harvard Business School Press: Boston, MA, USA, 1987.

44. Hermalin, B.E.; Weisbach, M.S. Understanding Corporate Governance Through Learning Models of Managerial Competence. Asia Pac. J. Financ. Stud. 2019, 48, 7-29. [CrossRef]

45. Hermalin, B.E.; Weisbach, M.S. Assessing managerial ability: Implications for corporate governance. In The Handbook of the Economics of Corporate Governance; Elsevier: Amsterdam, The Netherlands, 2017; Volume 1, pp. 93-176.

46. Hermalin, B.E.; Weisbach, M.S. Endogenously chosen boards of directors and their monitoring of the CEO. Am. Econ. Rev. 1998, 88, 96-118.

47. Adams, R.B.; Hermalin, B.E.; Weisbach, M.S. The role of boards of directors in corporate governance: A conceptual framework and survey. J. Econ. Lit. 2010, 48, 58-107. [CrossRef]

48. Baker, M.; Gompers, P.A. The Determinants of Board Structure at the Initial Public Offering. J. Law Econ. 2003, 46, 569-598. [CrossRef]

49. Cook, M.L.; Burress, M.J. The Impact of CEO Tenure on Cooperative Governance. Manag. Decis. Econ. 2013, 34, 218-229. [CrossRef]

50. Ling, K.C.; Liebrand, C. New Approach to Measuring Dairy Cooperative Performance; US Department of Agriculture, Rural Business and Cooperative Service: Washington, DC, USA, 1998.

51. Chaddad, F. Measuring the Economic Performance of Cooperatives: An Evaluative Survey of the Literature. In Working Paper AEWP 2001-1, Department of Agricultural Economics; University of Missouri: Columbia, MO, USA, 2001.

52. Liebrand, C.B. Measuring the Performance of Agricultural Cooperatives; US Department of Agriculture, Rural Business and Cooperative Programs: Washington, DC, USA, 2007.

53. Pearce, J.A.; Zahra, S.A. The relative power of CEOs and boards of directors: Associations with corporate performance. Strateg. Manag. J. 1991, 12, 135-153. [CrossRef]

54. 2010 Spencer Stuart Board Index, 25th ed.; Spencer Stuart Board Services: Chicago, IL, USA, 2010.

55. Zellner, A.; Theil, H. Three-stage least squares: Simultaneous estimation of simultaneous equations. Econometrica 1962, 30, 54-78. [CrossRef]

56. Mikhail, W. A comparative Monte Carlo study of the properties of econometric estimators. J. Am. Stat. Assoc. 1975, 70, 94-104. [CrossRef]

57. Greene, W.H. Econometric Analysis, 6th ed.; Pearson Prentice Hall: Upper Saddle River, NJ, USA, 2008.

58. Browne, M.W.; Cudeck, R. Single sample cross-validation indices for covariance structures. Multivar. Behav. Res. 1986, 24, 445-455. [CrossRef] [PubMed]

59. Hair, J.F.; Anderson, R.E.; Tanham, R.L.; Black, W.C. Multivariate Data Analysis; Prentice Hall, Inc.: Englewood Cliffs, NJ, USA, 1995.

60. Wooldridge, J.M. Econometric Analysis of Cross Section and Panel Data; MIT Press: Cambridge, MA, USA, 2002.

61. Boone, A.L.; Casares Field, L.; Karpoff, J.M.; Raheja, C.G. The determinants of corporate board size and composition: An empirical analysis. J. Financ. Econ. 2007, 85, 66-101. [CrossRef]

62. Gompers, P.; Ishii, J.; Metrick, A. Corporate governance and equity prices. Q. J. Econ. 2003, 118, 107-156. [CrossRef]

63. Linck, J.S.; Netter, J.M.; Yang, T. The determinants of board structure. J. Financ. Econ. 2008, 87, 308-328. [CrossRef]

64. Mason, C.H.; Perreault, W.D., Jr. Collinearity, power, and interpretation of multiple regression analysis. J. Mark. Res. 1991, 268-280. [CrossRef] 
65. Sribney, W.; Wiggins, V.; Drukker, D. Negative and Missing R-Squared for 2SLS/IV. Available online: http://www.stata.com/support/faqs/stat/2sls.html (accessed on 23 January 2013).

66. Cook, M.L. The Future of US Agricultural Cooperatives: A Neo-Institutional Approach. Am. J. Agric. Econ. 1995, 77, 1153-1159. [CrossRef]

67. Coles, J.L.; Daniel, N.D.; Naveen, L. Boards: Does one size fit all? J. Financ. Econ. 2008, 87, 329-356. [CrossRef]

68. Pennings, J.M.E.; Garcia, P. Measuring Producers' Risk Preferences: A Global Risk-Attitude Construct. Am. J. Agric. Econ. 2001, 83, 993-1009. [CrossRef]

69. Haigh, M.S.; Bessler, D.A. Causality and Price Discovery: An Application of Directed Acyclic Graphs. J. Bus. 2004, 77, 1099-1121. [CrossRef]

70. Franken, J.R.V.; Parcell, J.L.; Tonsor, G.T. Impact of mandatory price reporting on hog market integration. J. Agric. Appl. Econ. 2011, 43, 229-241. [CrossRef]

71. Franken, J.R.V.; Pennings, J.M.E.; Garcia, P. Crop Production Contracts and Marketing Strategies: What Drives Their Use? Agribusiness 2012, 28, 324-340. [CrossRef]

(C) 2019 by the authors. Licensee MDPI, Basel, Switzerland. This article is an open access article distributed under the terms and conditions of the Creative Commons Attribution (CC BY) license (http://creativecommons.org/licenses/by/4.0/). 